\title{
Evolutionary Process from Mockina bidentata to Parvigondolella andrusovi: Evidence from the Pizzo Mondello Section, Sicily, Italy
}

\author{
Yixing Du ${ }^{* 1}{ }^{1}$, Tetsuji Onoue ${ }^{2}$, Viktor Karádi ${ }^{3}$, Ian S. Williams ${ }^{4}$, Manuel Rigo ${ }^{1,5}$ \\ 1. Department of Geosciences, University of Padova, 35131 Padova, Italy \\ 2. Department of Earth and Planetary Sciences, Kyushu University, Fukuoka, Japan \\ 3. Department of Palaeontology, Eötvös Loránd University, Budapest 1117, Hungary \\ 4. Research School of Earth Sciences, The Australian National University, ACT 2601 Canberra, Australia \\ 5. Institute of Geosciences and Earth Resources, National Research Council of Italy, 35131 Padova, Italy \\ (D) Yixing Du: https://orcid.org/0000-0001-6397-1494
}

\begin{abstract}
During their last phase of evolution, the pectiniform conodont elements manifested an evident trend of simplification and miniaturization. This phase started from the late Norian (Sevatian) in the Late Triassic and the evolutionary process of genus Mockina to Parvigondolella, in particular between Mockina bidentata and Parvigondolella andrusovi, is one of the most significant examples. Parvigondolella has been reported worldwide since it was first described in the early 1970s. However, it has recently been suggested that genus Parvigondolella is an ecostratigraphic morphotype of genus Mockina, and thus a phenotype controlled by the environmental conditions, and not an independent taxon. In the Pizzo Mondello Section (Sicily, Italy), transitional forms between $M$. bidentata and $P$. andrusovi have been found at different evolutionary stages. We have investigated the oceanic conditions at the time by using redox-sensitive elements $(\mathrm{Mn}, \mathrm{Fe}, \mathrm{V}, \mathrm{Cr}$, and $\mathrm{Ni}$ ) and seawater temperatures from biogenetic $\delta^{18} \mathrm{O}_{\text {phos }}$ to understand the possible environmental influences on the phylogenetic evolution between Mockina and Parvigondolella. The geochemical and isotope analyses indicate that the redox condition and temperature were stable during the evolution of genus Parvigondolella in Pizzo Mondello, confirming that genus Parvigondolella is a real taxon and not a phenotype. A new conodont species named Parvigondolella ciarapicae $\mathbf{n}$. sp. is described here for the first time.
\end{abstract}

KEY WORDS: conodont, Late Triassic, evolution, oxygen isotope, geochemistry.

\section{INTRODUCTION}

Conodonts are calcium phosphate tooth-like elements from an elaborate feeding apparatus of a marine vertebrate (e.g., Donoghue et al., 2000; Sansom et al., 1992) that became extinct near the Triassic/Jurassic boundary (Du et al., 2020a). Conodonts are a significant tool for global biostratigraphic correlations in particular to define the global boundary stratotypes (GSSPs) of the Upper Triassic stages (Mazza et al., 2018, 2011; Rigo et al., 2018, 2016; Bertinelli et al., 2016; Mietto et al., 2012).

Conodonts suffered several extinctions and/or faunal turnovers from the Carnian to the end of Rhaetian before their final extinction (e.g., Rigo et al., 2018). The first event was in the early Julian (early Carnian), when the ornamented budurovignathids disappeared. The simplified paragondolellids survived beyond that event (Kozur, 1989). Only a few conodont

*Corresponding author: yixing.du@outlook.com

(C) The Authors 2021. This article is published with open access at Springerlink.com, corrected publication in 2021

Manuscript received June 15, 2020.

Manuscript accepted October 29, 2020. taxa survived the second event, which corresponds to the Carnian Pluvial Episode occurring from Julian 2 (late Carnian) to the Julian/Tuvalian boundary (mid-Carnian) (Mazza et al., 2012a; Rigo et al., 2007). Faunal turnovers occurred at the Tuvalian/Lacian (Carnian/Norian) boundary (Mazza et al., 2012a, b, 2010). This interval is characterized by the development of the genus Epigondolella (=Ancyrogondolella sensu Orchard, 2018) and the mass emergence and, shortly afterwards, the sudden disappearance of the genus Metapolygnathus (with the exception of Me. mazzai).

Subsequently, conodonts evolved into two main phylogenetic trends: one was characterized by the absence of ornamentation on the platform margins and free blade (i.e., Norigondolella); the other was characterized by the development of nodes and then high denticles on the platform margins, such as Epigondolella and Mockina. A clear faunal turnover started in the Lacian/Alaunian boundary interval with the appearance of the genus Mockina and the subsequent demise of the genus Epigondolella. The last event occurred over a long period, which started in the mid-Sevatian and led through several steps to the extinction of conodonts around the Triassic/Jurassic boundary (Du et al., 2020a; Karádi et al., 2020; Rigo et al.,

Du, Y. X., Onoue, T., Karádi, V., et al., 2021. Evolutionary Process from Mockina bidentata to Parvigondolella andrusovi: Evidence from the Pizzo Mondello Section, Sicily, Italy. Journal of Earth Science, 32(3): 667-676. https://doi.org/10.1007/s12583-020-1362-2. http://en.earth-science.net 
2020; Kozur and Mock, 1991; Orchard, 1983).

The diversity of Mockina species decreased during the Sevatian (Late Triassic) and the rise of atavistic homeomorphs (i.e., genus Parvigondolella and genus Misikella) is observed through evident simplifications of the pectiniform elements (Karádi et al., 2020; Giordano et al., 2010). These two different phylogenetic trends were considered to have evolved from the same common species Mockina bidentata, both by the loss of the platform and a decrease in size (Karádi et al., 2020; Rigo et al., 2018). These morphological trends have been observed by several researchers working on different stratigraphic sections worldwide (Du et al., 2020b; Karádi et al., 2020; Rigo et al., 2018, 2005; Mazza and Martínez-Pérez, 2015; Mazza et al., 2012b; Orchard et al., 2007a, b; Kozur and Mock, 1991). Thus, $M$. bidentata has been regarded as the common ancestor of the genus Parvigondolella (e.g., Karádi et al., 2020; Rigo et al., 2018; Moix et al., 2007; Kozur and Mock, 1991) and recently of Misikella (Karádi et al., 2020; Rigo et al., 2018, 2005).

Although Parvigondolella was reported both in Tethys and Panthalassa after its definition by Kozur and Mock (1972), there is still controversy about whether this genus is a real genus or not (Gallet et al., 2007; Krystyn et al., 2007a, b). However, the Parvigondolella is commonly found worldwide, such as in Italy, Austria, Hungary, Slovenia, Canada, America, Mexico, Russia and Japan (Zhang et al., 2019; Rigo et al., 2018, 2005; Mazza and Martínez-Pérez, 2015; Gale et al., 2012; Carter and Orchard, 2007; Krystyn et al., 2007a; Moix et al., 2007; Orchard et al., 2007a, b; Pálfy et al., 2007; Bragin, 1991; Kozur, 1989; Kunihiro et al., 1984; Kozur and Mostler, 1971), especially for the species $P$. andrusovi. At present, there seems to be a general consensus that Parvigondolella is the descendant of M. bidentata, and it has been recently proved by integrating phylogenetic and biostratigraphic approaches with numerical cladistic analyses (e.g., Karádi et al., 2020). In this paper, we report morphoclines between Mockina bidentata and Parvigondolella andrusovi collected from the Pizzo Mondello Section. We document the ocean conditions during this evolution by using redox-sensitive elements (e.g., Mn, Fe, Cr, V, and $\mathrm{Ni}$ ) and the oxygen isotope profile of conodont apatite to test if
Parvigondolella might be interpreted as an ecostratigraphic morphotype of $M$. bidentata in an unfavourable environment (Gallet et al., 2007; Krystyn et al., 2007a, b), or should be considered as an independent taxon.

\section{GEOLOGICAL SETTING}

The Pizzo Mondello Section (Fig. 1) is located in the southern Sicani Basin in western-central Sicily (Italy) (e.g., Mazza et al., 2010; Muttoni et al., 2004, 2001; Gullo, 1996; Bellanca et al., 1995). It is one of the longest continuous and well-exposed successions for the study of the Upper Triassic biostratigraphy, chemostratigraphy, magnetostratigraphy of the Tethyan realm, and it has been proposed as a GSSP candidate for the base of the Norian Stage (Mazza et al., 2018; Balini et al., 2010; Nicora et al., 2007).

The $430 \mathrm{~m}$ lower part of the section consists of Upper Triassic Mufara Formation and overlying Scillato Formation. The Mufara Formation consists of Carnian marly limestone and dark grey marl (Onoue et al., 2018), whereas the Scillato Formation consists of late Carnian to early Rhaetian (Mazza et al., 2012b; Muttoni et al., 2004, 2001; Gullo, 1996), evenly-bedded to nodular Halobia-bearing cherty calcilutites, the Calcari con Selce (or cherty limestone) sensu Muttoni et al. (2004, 2001). The section is characterized by almost uniform facies and high sedimentation rates of 22-30 m/Ma (Mazza et al., 2012b, 2010; Balini et al., 2010; Guaiumi et al., 2007; Muttoni et al., 2004, 2001). Overlying the thick Scillato succession is a thin $(20 \mathrm{~m})$ lower to middle Rhaetian succession of calcilutites, marls, and the Portella Gebbia Limestone, that is locally covered unconformably by Jurassic strata (Preto et al., 2013, 2012; Guaiumi et al., 2007; Gullo, 1996).

The lower succession of the Pizzo Mondello Section is well exposed in the abandoned La Cava quarry (Mazza et al., 2018, 2010; Onoue et al., 2018; Muttoni et al., 2004, 2001). The samples for this study were collected from the uppermost part of the section, between 349 and $369 \mathrm{~m}$ (Fig. 2). That part is characterized by almost uniform facies and yields large amounts of conodonts, including different growth stages, such as juvenile, adult and transitional forms, thus making Pizzo

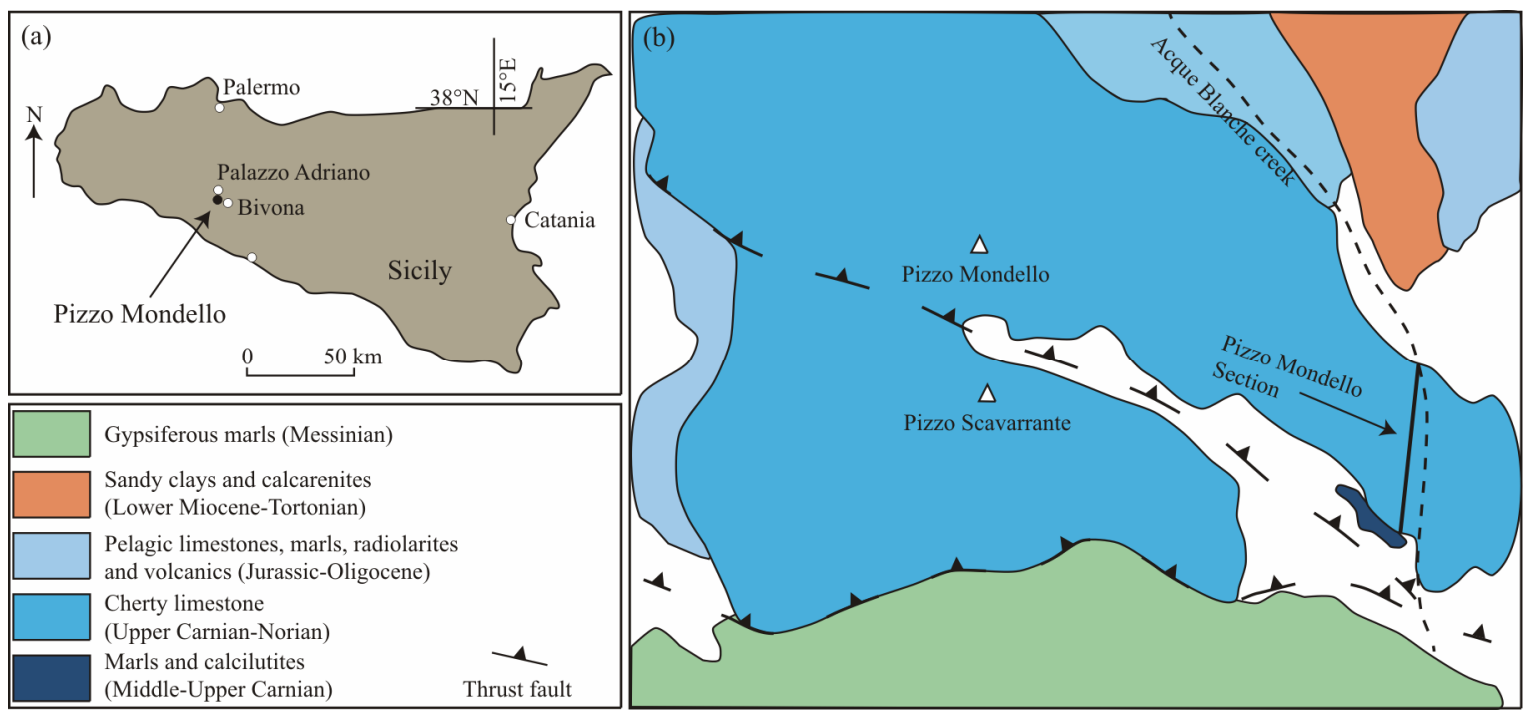

Figure 1. Sketch maps showing the location (a) and geological characteristics (b) of the Pizzo Mondello Section in Sicily, Italy (modified after Onoue et al., 2018). 


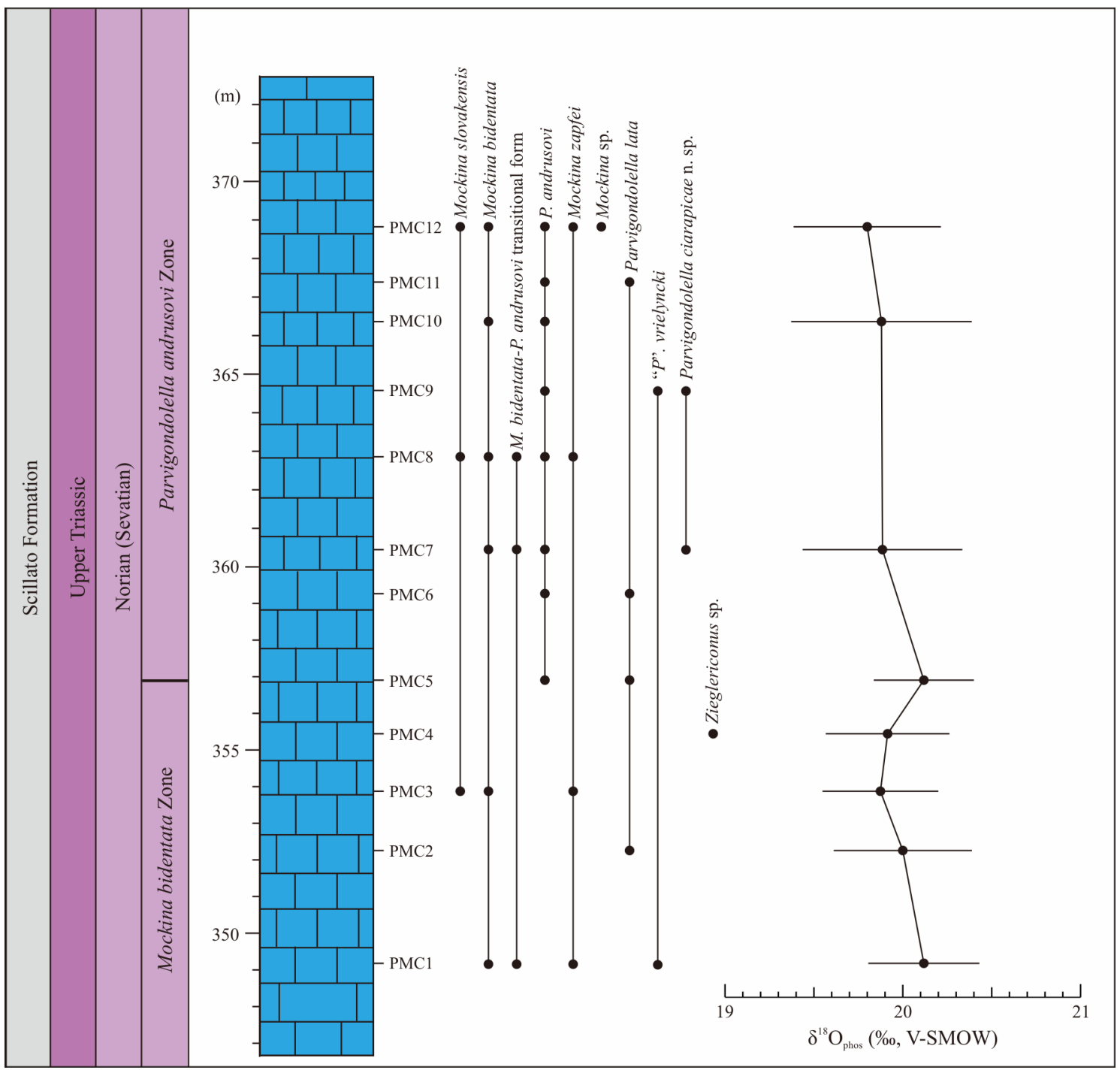

Figure 2. Studied portion of the Pizzo Mondello Section, between 349 and $369 \mathrm{~m}$ from Onoue et al. (2018). The uniform lithology consists of light lime mudstones. Conodont biozonation after Rigo et al. (2018). Oxygen isotope composition of biogenic conodont apatite $\left(\delta^{18} \mathrm{O}_{\text {phos}}\right)$ is analyzed by SHRIMP and all data were normalized to NBS120c (21.7\%).

Mondello suitable for a detailed study of the Upper Triassic conodont populations and evolution (Mazza and Martìnez-Pérez, 2015).

\section{MATERIALS, METHODS AND RESULTS}

\subsection{Conodonts}

Twelve conodont samples ( $\sim 2 \mathrm{~kg}$ of rock per sample) were crushed into small pieces about $2-3 \mathrm{~cm}$ and then placed in formic acid until the sample was completely dissolved. After that, the residues of the samples were washed in a $100 \mu \mathrm{m}$ sieve and then dried in a $40{ }^{\circ} \mathrm{C}$ oven. The resulting residues were collected and then examined under a microscope. The photos of conodonts were taken by a scanning electron microscope in the Department of Geosciences, University of Padova (Italy).

The distribution of conodonts in the upper part of the Pizzo Mondello Section (349-369 m) is illustrated in Fig. 2. It consists of the typical upper Norian association composed of conodonts Mockina bidentata, Mockina zapfei, Mockina slovakensis, Zieglericonus sp., Parvigondolella andrusovi and Parvigondolella lata. The presence of the two index species identifies the Mockina bidentata Zone and the Parvigondolella andrusovi Zone (from ca. $357 \mathrm{~m}$ ) sensu Rigo et al. (2018). The transitional forms between $M$. bidentata and $P$. andrusovi (morphocline) with only one denticle on the platform margin or one vestigial platform without denticle have been found between about 349 and $363 \mathrm{~m}$. A new Parvigondolella species which was named Parvigondolella ciarapicae n. sp. is established (Fig. 3).

\subsection{Oxygen Isotope Analyses}

Well-preserved pectiniform species and thermally unaltered conodonts $(\mathrm{CAI}=1)$ were selected and analyzed by high resolution SIMS (SHRIMP) for $\delta^{18} \mathrm{O}_{\text {phos }}$, following the established analytical strategy described by Trotter et al. $(2015,2008)$ and Rigo et al. (2012). All the SHRIMP analyses were referred to the primary apatite standard Durango 3 , the $\delta^{18} \mathrm{O}$ composition of which is $9.8 \%{ }_{0} \pm 0.25 \%$ determined by GIRMS and normalized to NBS120c $=21.7 \%$. The standard deviation of Durango 3 by SHRIMP analyses was $0.2 \%{ }^{-}-0.3 \%$. The results are shown in Fig. 2 and Table 1. 


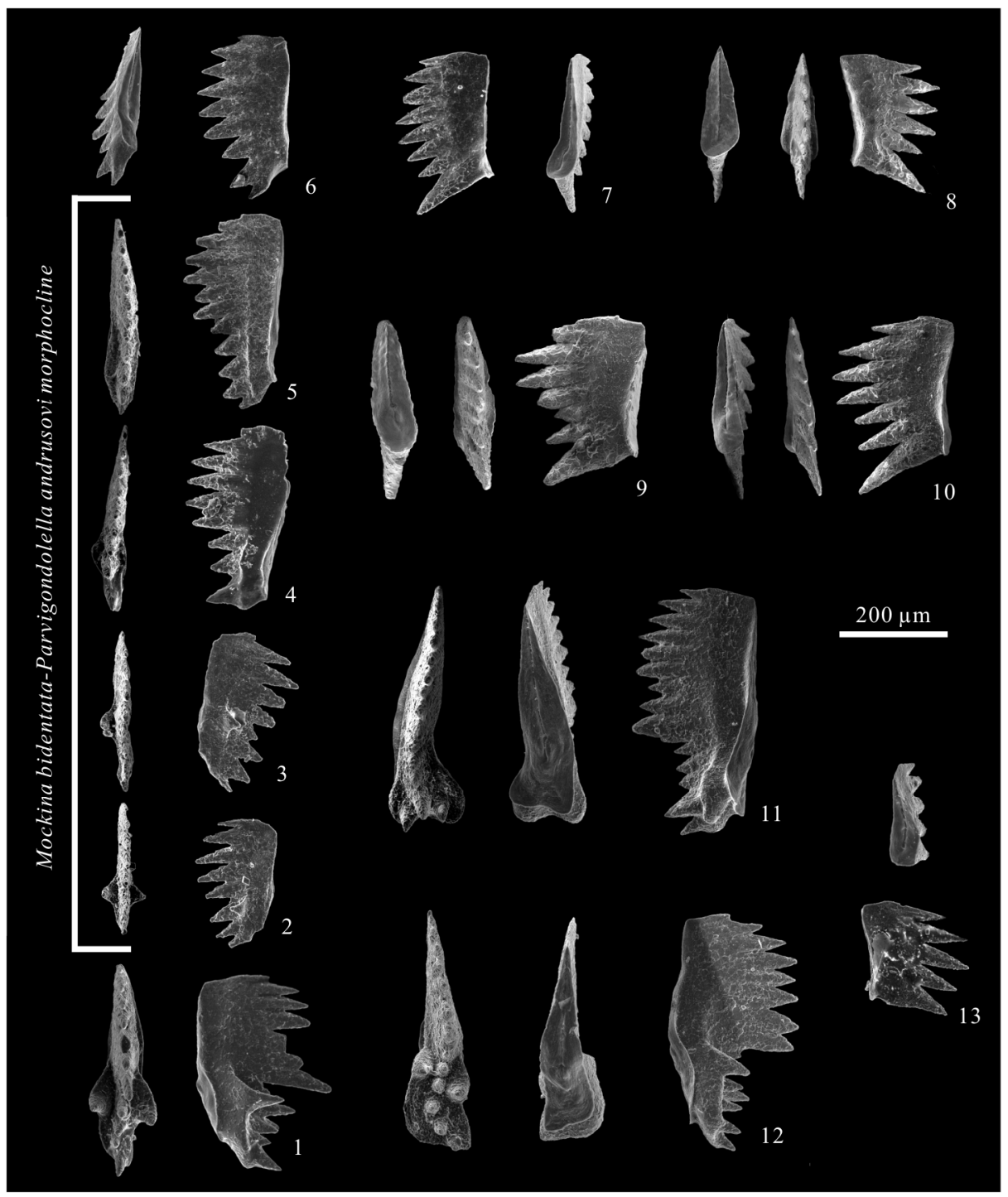

Figure 3. SEM photographs of conodonts from Pizzo Mondello Section. 1, 2. Mockina bidentata, 1 from PMC3, 2 from PMC1; 3, 4, 5. transitional forms between Mockina bidentata and Parvigondolella andrusovi, 3 from PMC1, 4 from PMC8, 5 from PMC8; 6. Parvigondolella andrusovi, PMC6; 7, 8, 9, 10. Parvigondolella ciarapicae n. sp., 10 is the holotype, 7, 8, 9, 10 from PMC9; 11. Mockina sp., PMC12; 12. Mockina zapfei, PMC12; 13. Parvigondolella lata, PMC5.

\subsection{Major and Trace Element Analyses}

For the geochemical analyses, we used limestone samples collected by Onoue et al. (2018) from the upper part of the Pizzo Mondello Section. The samples were pulverized in an agate mortar and a ball mill. Major elements and $\mathrm{V}, \mathrm{Cr}$, and $\mathrm{Ni}$ concentrations were determined by X-ray fluorescence spectrometry (XRF) using a PANalytical Epsilon $3^{\mathrm{XLE}}$ with Mo $\mathrm{X}$-ray tube following the sample preparation and analytical methods described by Onoue et al. (2016). Detection limits for trace elements were $9 \mathrm{ppm}$ for $\mathrm{V}$ and $3 \mathrm{ppm}$ for $\mathrm{Cr}$ and $\mathrm{Ni}$. Reproducibility, based on the replicate analysis of four standards (JDo-1, JLs-1, JSd-1, and JSd-2), was better than $\pm 1 \%$ for $\mathrm{V}$, better than $\pm 2 \%$ for $\mathrm{Cr}$ and better than $\pm 5 \%$ for $\mathrm{Ni}$.

To compare enrichments of elements, concentrations are given in the form of enrichment factors in which sample concentrations are normalized using $\mathrm{Ti}$ concentrations and compared with the composition of the upper continental crust (UCC; Rudnick and Gao, 2014). The enrichment factor is defined as

$$
\mathrm{X}_{\mathrm{EF}}=\left(\mathrm{X}_{\text {sample }} / \mathrm{Ti}_{\text {sample }}\right) /\left(\mathrm{X}_{\mathrm{UCC}} / \mathrm{Ti}_{\mathrm{UCC}}\right)
$$

where $\mathrm{X}$ and Ti are the weight concentrations of element $\mathrm{X}$ and $\mathrm{Ti}$, respectively.

Stratigraphic variations in the enrichment factors for redoxsensitive elements ( $\mathrm{Mn}, \mathrm{Fe}, \mathrm{V}, \mathrm{Cr}$, and $\mathrm{Ni}$ ) are shown in Table 2. Of these redox sensitive elements, $\mathrm{Mn}$ and $\mathrm{Fe}$ are useful to constrain ancient oceanic redox conditions, because their valency can vary as a function of the prevailing redox potential (Calvert and Pedersen, 2007, 1993). The enrichment factors of $\mathrm{Mn}\left(\mathrm{Mn}_{\mathrm{EF}}\right.$, ranging from 2.8 to 21.5 ) exhibit limited fluctuations throughout the studied section and generally parallel to the UCC line. $\mathrm{Fe}_{\mathrm{EF}}$ values are also constant in the studied section and close to a UCC value of 1 . Redox conditions in the seawater overlying the sediments were also inferred on the basis of the $\mathrm{V} /(\mathrm{V}+\mathrm{Ni})$ and $\mathrm{V} / \mathrm{Cr}$ indices (Soda and Onoue, 2019; Onoue et al., 2016; Wignall et al., 2007; Jones and Manning, 1994; Hatch and Leventhal, 1992). The V/Cr ratios are relatively constant $(0.35-0.95)$ throughout the studied section. Stratigraphic variations in $\mathrm{V} /(\mathrm{V}+\mathrm{Ni})$ ratios parallel those of $\mathrm{V} / \mathrm{Cr}$ ratios, and are in the range of $0.09-0.22$ (Fig. 4 and Table 2). 


\section{DISCUSSION}

Conodonts show an evident evolutionary tendency to decrease in size from the Latest Triassic (Rigo et al., 2018). This process is characterized by the simplification of the pectiniform elements by the loss of the platform, in particular during the evolutionary process from Mockina to both Misikella and Parvigondolella (e.g., Karádi et al., 2020).

Mockina bidentata is a small and slender pectiniform element with a relatively short and reduced platform. The platform of some transitional elements is extremely reduced, sometimes vestigial or even absent, and only a pair of large denticles is present on the anterior margins. In addition, a small accessory node may be irregularly developed on one side of the anterior
Table $1 \quad \delta^{18} \mathrm{O}_{\text {phos }}$ data of conodont samples from the upper part of the Pizzo Mondello Section

\begin{tabular}{lccccc}
\hline Sample & Conodont species & $\mathrm{CAI}$ & $\delta^{18} \mathrm{O}_{\text {phos }}$ & $95 \% \mathrm{cl}$ & Height $(\mathrm{m})$ \\
\hline PMC12 & $\begin{array}{c}\text { M. bidentata/ } \\
\text { P. andrusovi trans. }\end{array}$ & 1 & 19.80 & 0.41 & 368.7 \\
PMC10 & P. andrusovi & 1 & 19.88 & 0.51 & 366.4 \\
PMC7 & P. andrusovi & 1 & 19.89 & 0.44 & 360.4 \\
PMC5 & P. andrusovi & 1 & 20.11 & 0.29 & 357.9 \\
PMC4 & P. lata & 1 & 19.91 & 0.35 & 355.4 \\
PMC3 & M. bidentata & 1 & 19.87 & 0.33 & 353.9 \\
PMC2 & P. lata & 1 & 20.00 & 0.39 & 352.2 \\
PMC1 & M. bidentata & 1 & 20.11 & 0.32 & 349.1 \\
\hline & & & & &
\end{tabular}

Table 2 Major and trace element compositions of limestone samples from the upper part of the Pizzo Mondello Section

\begin{tabular}{|c|c|c|c|c|c|c|c|c|c|c|c|}
\hline Sample & Height (m) & $\mathrm{TiO}_{2}{ }^{\mathrm{a}}(\mathrm{wt} . \%)$ & $\mathrm{Fe}_{2} \mathrm{O}_{3}{ }^{\mathrm{a}, \mathrm{b}}$ (wt.\%) & $\mathrm{MnO}^{\mathrm{a}}$ (wt.\%) & $\mathrm{Cr}(\mathrm{ppm})$ & $\mathrm{Ni}(\mathrm{ppm})$ & $\mathrm{V}(\mathrm{ppm})$ & $\mathrm{FeEF}^{\mathrm{c}}$ & $\mathrm{MnEF}^{\mathrm{c}}$ & $\mathrm{V} / \mathrm{Cr}$ & $\mathrm{V} /(\mathrm{V}+\mathrm{Ni})$ \\
\hline PMN212 & 406.3 & 0.02 & 0.15 & 0.03 & 29 & 89 & 16 & 1.0 & 11.1 & 0.56 & 0.15 \\
\hline PMN195 & 402.5 & 0.01 & 0.10 & 0.03 & 37 & 137 & 15 & 1.1 & 19.5 & 0.41 & 0.10 \\
\hline PMN175 & 397.2 & 0.01 & 0.10 & 0.04 & 37 & 154 & 23 & 1.1 & 21.5 & 0.61 & 0.13 \\
\hline PMN161 & 393.7 & 0.02 & 0.10 & 0.03 & 29 & 105 & 21 & 0.8 & 11.5 & 0.73 & 0.17 \\
\hline PMN136 & 389.9 & 0.01 & 0.10 & 0.04 & 33 & 117 & 12 & 0.9 & 17.5 & 0.35 & 0.09 \\
\hline PMN120 & 383.8 & 0.01 & 0.08 & 0.02 & 33 & 158 & 23 & 0.9 & 12.3 & 0.70 & 0.13 \\
\hline PMNM26-4 & 377.4 & 0.01 & 0.10 & 0.03 & 30 & 106 & 22 & 1.0 & 14.7 & 0.72 & 0.17 \\
\hline PMN89 & 369.6 & 0.04 & 0.22 & 0.02 & 32 & 95 & 24 & 0.8 & 2.8 & 0.73 & 0.20 \\
\hline PMN85 & 368.0 & 0.02 & 0.09 & 0.02 & 33 & 145 & 15 & 0.6 & 5.2 & 0.45 & 0.09 \\
\hline PMN80 & 366.8 & 0.01 & 0.05 & 0.02 & 35 & 188 & 23 & 0.7 & 13.4 & 0.65 & 0.11 \\
\hline PMN76 & 365.6 & 0.01 & 0.07 & 0.01 & 30 & 125 & 21 & 0.7 & 7.3 & 0.72 & 0.14 \\
\hline PMN70 & 364.5 & 0.01 & 0.05 & 0.02 & 32 & 196 & 29 & 0.6 & 11.5 & 0.91 & 0.13 \\
\hline PMN65 & 363.5 & 0.01 & 0.04 & 0.02 & 37 & 192 & 30 & 0.6 & 12.0 & 0.81 & 0.13 \\
\hline PMN60 & 360.6 & 0.01 & 0.07 & 0.02 & 38 & 131 & 17 & 1.0 & 14.4 & 0.44 & 0.11 \\
\hline PMN55 & 359.3 & 0.02 & 0.14 & 0.02 & 35 & 125 & 20 & 0.7 & 5.4 & 0.57 & 0.14 \\
\hline PMN50 & 358.0 & 0.04 & 0.21 & 0.02 & 30 & 88 & 25 & 0.8 & 3.6 & 0.81 & 0.22 \\
\hline PMN45 & 357.1 & 0.01 & 0.07 & 0.02 & 38 & 144 & 24 & 0.7 & 9.4 & 0.62 & 0.14 \\
\hline PMN45-3 & 357.1 & 0.01 & 0.06 & 0.02 & 36 & 143 & 18 & 0.6 & 9.0 & 0.50 & 0.11 \\
\hline PMN15 & 350.2 & 0.02 & 0.13 & 0.02 & 33 & 114 & 18 & 0.8 & 5.1 & 0.56 & 0.14 \\
\hline PMN1 & 346.1 & 0.02 & 0.15 & 0.02 & 37 & 101 & 20 & 0.8 & 4.6 & 0.54 & 0.16 \\
\hline PMMN24 & 335.0 & 0.01 & 0.13 & 0.02 & 37 & 143 & 16 & 1.4 & 9.4 & 0.42 & 0.10 \\
\hline PMMN23 & 333.2 & 0.01 & 0.07 & 0.02 & 37 & 124 & 19 & 1.1 & 14.3 & 0.51 & 0.13 \\
\hline PMMN22 & 331.7 & 0.01 & 0.10 & 0.02 & 34 & 131 & 33 & 1.1 & 14.4 & 0.95 & 0.20 \\
\hline PMMN21 & 329.4 & 0.01 & 0.07 & 0.02 & 37 & 152 & 22 & 0.7 & 8.3 & 0.60 & 0.13 \\
\hline PMMN20 & 328.1 & 0.02 & 0.17 & 0.03 & 37 & 155 & 23 & 1.0 & 8.7 & 0.62 & 0.13 \\
\hline PMMN19 & 327.2 & 0.01 & 0.07 & 0.03 & 39 & 194 & 19 & 0.9 & 20.0 & 0.49 & 0.09 \\
\hline PMMN18 & 325.3 & 0.01 & 0.08 & 0.02 & 37 & 130 & 24 & 0.8 & 8.8 & 0.65 & 0.16 \\
\hline PMMN17 & 324.0 & 0.03 & 0.19 & 0.02 & 33 & 96 & 16 & 0.9 & 4.1 & 0.49 & 0.15 \\
\hline PMMN16 & 322.2 & 0.01 & 0.07 & 0.02 & 37 & 127 & 22 & 0.9 & 15.7 & 0.59 & 0.15 \\
\hline PMMN15 & 320.9 & 0.01 & 0.09 & 0.02 & 36 & 164 & 28 & 1.0 & 11.8 & 0.78 & 0.15 \\
\hline PMMN14 & 320.3 & 0.01 & 0.07 & 0.03 & 38 & 222 & 27 & 1.0 & 18.6 & 0.72 & 0.11 \\
\hline
\end{tabular}

a. After Onoue et al. (2018); ${ }^{\text {b }}$ Total iron as $\mathrm{Fe}_{2} \mathrm{O}_{3} ;{ }^{\mathrm{c}}$. Normalized by Ti concentration and compared with that of the UCC composition (Rudnick and Gao, 2014) as enrichment factors. 
platform margin. The cusp is followed by one to three additional denticles. Parvigondolella andrusovi is the type species of the genus Parvigondolella (Kozur and Mock, 1972). This element is composed of a single blade with seven to nine denticles; the cusp is never terminal. The basal cavity is shallow and narrow. Parvigondolella commonly ranges from upper Norian to lower Rhaetian, and its first occurrence (FO) is higher than the FO of M. bidentata and below the first occurrence of Misikella hernsteini (Karádi et al., 2020; Rigo et al., 2018).

Mockina bidentata, $P$. andrusovi and the transitional forms between these two species were found in the Pizzo Mondello Section. The transitional forms of M. bidentata with only one tiny denticle on the reduced platform margins and the form, which has only one reduced platform without any denticle were found in sample PMC1 from the upper part of the M. bidentata Zone. These kinds of transitional forms have already been reported and described by different researchers in different places, such as in the Lagonegro Basin, Italy (Giordano et al., 2011, 2010; Bazzucchi et al., 2005; Bertinelli et al., 2005; Reggiani et al., 2005; Rigo et al., 2005), Buda Hills and Csővár area, Hungary (Karádi et al., 2020; Kozur and Mock, 1991), Silická Brezová, Slovakia (Channell et al., 2003) and Steinbergkogel, Austria (Krystyn et al., 2007b).

Mockina bidentata has been regarded as the common ancestor of genus Parvigondolella (Karádi et al., 2020; Rigo et al., 2018; Moix et al., 2007; Kozur, 1989; Kozur and Mostler, 1971), and genus Misikella (Karádi et al., 2020), even though a $M$. bidentata/M. hernsteini transitional form was already illustrated in Rigo et al. (2005). However, some researchers debated whether Parvigondolella (i.e., P. andrusovi, P. lata) is an independent genus, suggesting instead that it is just the morphological variants or ecostratigraphic morphotypes of M. bidentata in unfavourable environments (e.g., Gallet et al., 2007; Krystyn et al., 2007a, b). Furthermore, this unproven hypothesis seems to neglect the fact that proteromorphosis is also documented in other marine organisms during the same stress period (Sevatian). The untwisting of spines of radiolarians (Guex et al., 2012) and the uncoiling of ammonites (Guex, 2006) coincide with the development of atavistic homeomorphs (e.g., Parvigondolella and Misikella) among conodonts.

By using a quantitative analysis of discrete morphological features of the two species, Karádi et al. (2020) proposed that the transitional morphocline between $M$. bidentata and $P$. andrusovi proceeded in two different phases. The first phase is characterized by the gradual loss of the posterior platform of $M$. bidentata, and thus the denticles on the platform margins. The second phase is characterized by the decrease and the fusion of the blade denticles. These two phases are both recorded in the morphocline (=transitional forms) observed in the Pizzo Mondello Section. The transitional form of the first phase is usually characterized by a much-reduced platform with two or only one tiny denticles on the platform margins. Sometimes there is just the vestige of the platform without any denticles. Moreover, the blade and the carina of the element resemble the shape of that in M. bidentata. During the second phase, the number of blade denticles is decreased, and the platform denticle or platform vestige is lost. The transitional forms between M. bidentata and P. andrusovi from the Pizzo Mondello Section confirm the phylogenetic relationship between these two species just as illustrated by Karádi et al. (2020).

In addition to the morphology, the geochemical data from the studied section add evidence about the Parvigondolella lifestyle. We investigated the oceanic redox conditions and seawater temperatures through the studied section using redoxsensitive elements $\left(\mathrm{Mn}, \mathrm{Fe}, \mathrm{V}, \mathrm{Cr}\right.$, and $\mathrm{Ni}$ ) and the $\delta^{18} \mathrm{O}$ from biogenic conodont apatite. Of the investigated elements, $\mathrm{Mn}$ is one of the most sensitive geochemical proxies for redox conditions in the oceanic environment. It forms insoluble $\mathrm{Mn}$ (III) or $\mathrm{Mn}(\mathrm{IV})$ hydroxides or oxides (e.g., $\mathrm{MnO}_{2}$ ) that are deposited rapidly in particulate form (Sholkovitz et al., 1994; Calvert and Pedersen, 1993). However, under dysoxic to anoxic conditions, $\mathrm{Mn}$ is reduced to $\mathrm{Mn}(\mathrm{II})$ and forms soluble cations (e.g., $\mathrm{Mn}^{2+}$ ). Consequently, a small enrichment factor for $\mathrm{Mn}\left(\mathrm{Mn}_{\mathrm{EF}}\right)$ in marine sediments would suggest reducing depositional conditions near the surface of the sediments.

Our analysis reveals that there is no significant fractionation of $\mathrm{Mn}_{\mathrm{EF}}$ in the studied section (Fig. 4). Therefore, significant redox changes across the $M$. bidentata and $P$. andrusovi conodont zones cannot be recognized from Mn. Enrichments of Fe have also been widely applied to marine carbonates in order to constrain ancient oceanic redox conditions (Clarkson et al., 2014; Johnston et al., 2012; Lyons et al., 2003). Throughout the studied section, $\mathrm{Fe}_{\mathrm{EF}}$ values are relatively constant across the $M$. bidentata and $P$. andrusovi zones and are similar to UCC values (Fig. 4). The $\mathrm{Mn}$ and $\mathrm{Fe}$ data demonstrate that the redox conditions in the studied section were stable and oxic across the $M$. bidentata and $P$. andrusovi zones.

We further examined the redox conditions based on the $\mathrm{V} / \mathrm{Cr}$ and $\mathrm{V} /(\mathrm{V}+\mathrm{Ni}$ ) indices (Fig. 4). Values of the $\mathrm{V} / \mathrm{Cr}$ ratio are statistically robust redox proxies predicted by multivariate statistical analysis on compositional data (Soda and Onoue, 2019; Jones and Manning, 1994), and classified by oxic, dysoxic, and anoxic conditions based on correlation with the degree of pyritization. Based on a classification proposed by Jones and Manning (1994), values of $\mathrm{V} / \mathrm{Cr}<2$ are indicative of oxic environments. The $\mathrm{V} / \mathrm{Cr}$ ratios in the studied section are generally less than one, which suggests deposition in an oxic environment. The $\mathrm{V} /(\mathrm{V}+\mathrm{Ni})$ ratio of sediments can be used to determine oxygenation trends without adherence to specific thresholds (Onoue et al., 2016; Wignall et al., 2007; Rimmer, 2004; Schovsbo, 2001). The stratigraphic variations in $\mathrm{V} /(\mathrm{V}+\mathrm{Ni})$ ratios show constant low values $(<0.2)$ across the $M$. bidentata and $P$. andrusovi zones and there are no significant stratigraphic variations throughout the studied section. Consequently, our analysis of redox-sensitive elements indicates there was no redox change in the upper part of the Pizzo Mondello Section.

Similarly, the $\delta^{18} \mathrm{O}_{\text {phos }}$ isotopic composition of biogenic (conodont) apatite is almost constant throughout the studied section, with an average value of $19.95 \%$ and a standard deviation from the mean value of $0.12 \%$ (Table 1 ). Oxygen isotopes can be used to understand perturbations of the climate over geological time since oxygen isotopes might be affected by changes in ocean temperature (e.g., Trotter et al., 2015; Rigo et al., 2012; Rigo and Joachimski, 2010). Throughout the studied section the $\delta^{18} \mathrm{O}_{\text {phos }}$ shows minimal variations, indicating minimal changes in the ocean paleotemperatures, proving that the 

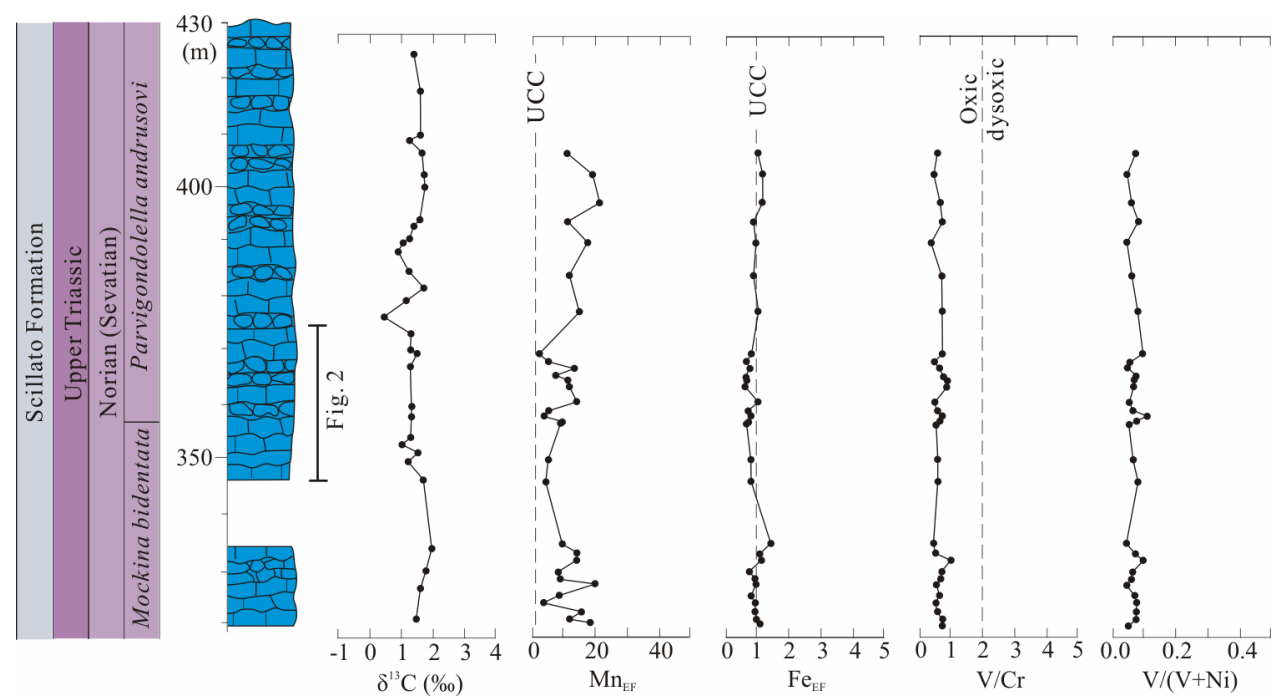

Figure 4. Stratigraphic variations in $\delta^{13} \mathrm{C}$ (Muttoni et al., 2004), enrichment factors of $\mathrm{Mn}\left(\mathrm{Mn}_{\mathrm{EF}}\right)$ and $\mathrm{Fe}\left(\mathrm{Fe}_{\mathrm{EF}}\right)$, and redox index $(\mathrm{V} / \mathrm{Cr}$ and $\mathrm{V} /(\mathrm{V}+\mathrm{Ni}))$ values from limestone samples from the upper part of the Pizzo Mondello Section.

evolution of the genus Parvigondolella might not have been driven by changing climatic conditions.

In summary, the worldwide distribution and the diversity (P. andrusovi, P. lata, P. prorhaetica, and P. ciarapicae n. sp.) of the genus indicates that Parvigondolella is not an ecostratigraphic morphotype of Mockina (M. bidentata) in unfavourable environments. The facts that parvigondolellids and the transitional forms (=morphocline) between Mockina bidentata and Parvigondolella occurred in very different paleogeographical regions suggest that this genus was not dependent on the redox conditions/temperature conditions of its habitat. Although the development of the genus Parvigondolella might have been the result of a not yet studied factor, most probably related to the supply or the type of food, its stratigraphic range and morphological characters are obviously different from the genera Mockina and Misikella, which confirms Parvigondolella to be as valid and real genus as the other two taxa.

\section{SYSTEMATIC PALEONTOLOGY}

Genus Mockina Kozur, 1989

Type species: Tardogondolella abneptis postera Kozur and Mostler, 1971

Description: The genus Mockina has sharp and high denticles on the anterior platform margins. The posterior platform can be unornamented or can bear low denticles. The platform is reduced in width, or extremely simplified in some species. The pit is always forward shifted and a posterior prolongation of the keel is present. The keel end is mostly pointed or narrowly rounded, sometimes blunt or rarely slightly bifurcated. The posterior carina behind the cusp is composed of two-three denticles.

Comparison: The genus Epigondolella has a broader platform, often posteriorly widening. The platform is usually strongly ornamented. The epigondolellids have a centrally located pit and a strongly bifurcated keel termination.

Stratigraphic range: From middle Norian to lower Rhaetian.

Mockina sp.

Fig. 3/11
Material: One specimen from one sample (PMC12).

Remarks: Although there is only one specimen found, this conodont cannot be assigned to any known species.

Description: Mockina sp. has an extremely short and reduced platform. A slight incision in the middle of the posterior platform margin divides the platform into two lobes. Each lobe has a sharp denticle near the posterior margin, resembling the teeth of a vampire. The blade is long and it is almost three quarters of the entire element. The blade descends relatively abrupt onto the platform. The cusp is anteriorly shifted and followed by one large carinal denticle. Its lower surface is all occupied by the keel, which follows the platform outline in shape. The pit is narrow and shallow, and it strongly shifted forward.

Comparison: Mockina bidentata also has an extremely reduced platform, but it is slender. The two sharp denticles of $M$. bidentata occur on the anterior platform margins, but the denticles of Mockina sp. are near the posterior edge of the platform.

Occurrence: The species occurs in the Sevatian (within the P. andrusovi Zone) in the Pizzo Mondello Section.

Genus Parvigondolella Kozur and Mock, 1972

Type species: Parvigondolella andrusovi Kozur and Mock, 1972

Description: The genus Parvigondolella is characterized by a single blade with high denticles that are fused only at their bases. It completely lacks a platform. The basal furrow is narrow and shallow. The pit can be located terminally or behind the mid-length of the unit.

Comparison: Genus Mockina always has a platform, even if sometimes it may be extremely reduced. Genus Misikella lacks the platform but it has a deep and broad basal cavity.

Stratigraphic range: From Sevatian to Rhaetian.

Parvigondolella ciarapicae n. sp. Rigo and Du

Figs. 3/7, 8, 9, 10

2007 Parvigondolella sp. A. Orchard, Orchard et al., figs. $7 / 15,7 / 16$.

Derivatio nominis: In memory of Gloria Ciarapica, for 
her outstanding studies of geology of Italy.

Holotype: The specimen in Fig. 3/10; deposited in the Department of Geosciences, University of Padova; sample PMC9.

Locus typicus: Pizzo Mondello Section, Sicily, Italy.

Stratum typicum: Sample from $360.4 \mathrm{~m}$ of the Pizzo Mondello Section, Sicily, Italy. It occurred in limestone belonging to the Scillato Formation; Parvigondolella andrusovi Interval Zone.

Material: Nine specimens from two samples (PMC7 and PMC9).

Diagnosis: The blade of Parvigondolella ciarapicae n. sp. has six to eight denticles. The cusp is located terminally and it is the largest denticle of the blade. The basal furrow is shallow and narrow.

Description: The blade of Parvigondolella ciarapicae $\mathrm{n}$. sp. is relatively long with six to eight denticles. The cusp is always located terminally and it is usually stronger than the other denticles of the blade. The blade is always the highest in the middle part, and the prominent cusp is in all cases higher than the preceding one or two denticles. The pit is just below the cusp and it is located at the posterior end. The basal furrow is shallow and narrow, but it is slightly widened at the pit. In lateral view, the unit is straight.

Comparison: Parvigondolella ciarapicae $\mathrm{n}$. $\mathrm{sp}$. is characterized by the strong cusp, which is always located at the posterior termination of the blade. The cusp of Parvigondolella andrusovi is not prominent and it is followed by one or two denticles. Parvigondolella lata has a terminal cusp but the blade of P. lata is shorter. Parvigondolella ciarapicae n. sp. could be distinguished from any Misikella species because of the narrow and shallow basal furrow, which is different from the deep and broad basal cavity of Misikella.

Occurrence: The Parvigondolella ciarapicae n. sp. occurs in the Sevatian (within the P. andrusovi Zone) in the Pizzo Mondello Section. It is present in beds of the same age in the Csővár area in Hungary. In North America, this species was found in the Rhaetian (within the Proparvicingla moniliformis radiolarian zone).

\section{CONCLUSIONS}

New investigations have confirmed the phylogenetic relationship between the conodont genera Mockina and Parvigondolella, proven by transitional forms belonging to the Mockina bidentata-Parvigondolella andrusovi morphocline collected from the upper part of the Pizzo Mondello Section (349 to 369 $\mathrm{m})$, Sicily, Italy. Geochemical analyses for paleoenvironmental proxies from bulk limestone samples demonstrate that the redox conditions in the studied section were stable and oxic across the $M$. bidentata and $P$. andrusovi zones. Similarly, $\delta^{18} \mathrm{O}_{\text {phos }}$ shows negligible changes in sea water temperature, hence no climatic perturbations.

The worldwide morphoclines between Mockina bidentata and $P$. andruvosi documented in Pizzo Mondello and other sections along with the geochemical and isotope evidences obtained from the Pizzo Mondello Section indicate that Parvigondolella is an independent genus rather than an ecostratigraphic morphotype of Mockina (M. bidentata) adapted to unfavourable environments.
A new conodont species, named Parvigondolella ciarapicae n. sp., has been established, which enriches the diversity of the genus Parvigondolella.

\section{ACKNOWLEDGMENTS}

We are grateful to Prof. Yanlong Chen and another anonymous reviewer for careful revision and comments on the manuscript. This study was supported by the grants PRIN to Manuel Rigo (No. 2017W2MARE); and the China Scholarship Council to Yixing Du (No. 201708510096). Development of conodont oxygen isotopic analysis by SHRIMP was supported by Australian Research Council Discovery to Ian S. Williams (No. DP1096252). Open Access funding provided by Università degli Studi di Padova. The final publication is available at Springer via https://doi.org/10.1007/s12583-020-1362-2.

Open Access This article is distributed under the terms of the Creative Commons Attribution 4.0 International License (http://creativecommons.org/licenses/by/4.0/), which permits unrestricted use, distribution, and reproduction in any medium, provided you give appropriate credit to the original author and the source, provide a link to the Creative Commons license, and indicate if changes were made.

\section{REFERENCES CITED}

Balini, M., Bertinelli, A., Di Stefano, P., et al., 2010. The Late Carnian-Rhaetian Succession at Pizzo Mondello (Sicani Mountains). Albertiana, 39: 36-57

Bazzucchi, P., Bertinelli, A., Ciarapica, G., et al., 2005. The Late Triassic-Jurassic Stratigraphic Succession of Pignola (Lagonegro-Molise Basin, Southern Apennines, Italy). Bollettino della Società Geologica Italiana, 124: 143-153

Bellanca, A., Di Stefano, P., Neri, R., 1995. Sedimentology and Isotope Geochemistry of Carnian Deep-Water Marl/Limestone Deposits from the Sicani Mountains, Sicily: Environmental Implications and Evidence for a Planktonic Source of Lime Mud. Palaeogeography, Palaeoclimatology, Palaeoecology, 114(1): 111-129. https://doi.org/10.1016/0031-0182(95)00077-y

Bertinelli, A., Ciarapica, G., Zanche, V. D., et al., 2005. Stratigraphic Evolution of the Triassic-Jurassic Sasso di Castalda Succession (Lagonegro Basin, Southern Apennines, Italy). Italian Journal of Geosciences, 124(1): 161-175

Bertinelli, A., Casacci, M., Concheri, G., et al., 2016. The Norian/Rhaetian Boundary Interval at Pignola-Abriola Section (Southern Apennines, Italy) as a GSSP Candidate for the Rhaetian Stage: An Update. Albertiana, 43: 5-18

Bragin, N., 1991. Radiolarians and Lower Mesozoic Deposits in the Eastern USSR. Nauka, Moscow. 125

Calvert, S. E., Pedersen, T. F., 1993. Geochemistry of Recent Oxic and Anoxic Marine Sediments: Implications for the Geological Record. Marine Geology, 113(1/2): 67-88. https://doi.org/10.1016/0025-3227(93)90150-t

Calvert, S. E., Pedersen, T. F., 2007. Chapter Fourteen Elemental Proxies for Palaeoclimatic and Palaeoceanographic Variability in Marine Sediments: Interpretation and Application. In: Hillaire-Marcel, C., Vernal, A. D., eds., Developments in Marine Geology, Vol. 1. Elsevier, Amsterdam. 567-644

Carter, E. S., Orchard, M. J., 2007. Radiolarian-Conodont-Ammonoid Intercalibration around the Norian-Rhaetian Boundary and Implications for Trans-Panthalassan Correlation. Albertiana, 36: 149-163

Channell, J. E. T., Kozur, H. W., Sievers, T., et al., 2003. Carnian-Norian Biomagnetostratigraphy at Silická Brezová (Slovakia): Correlation to Other Tethyan Sections and to the Newark Basin. Palaeogeography, Palaeoclimatology, Palaeoecology, 191(2): 65-109. https://doi.org/10.1016/s0031-0182(02)006545

Clarkson, M. O., Poulton, S. W., Guilbaud, R., et al., 2014. Assessing the 
Utility of $\mathrm{Fe} / \mathrm{Al}$ and Fe-Speciation to Record Water Column Redox Conditions in Carbonate-Rich Sediments. Chemical Geology, 382: 111-122. https://doi.org/10.1016/j.chemgeo.2014.05.031

Donoghue, P. C. J., Forey, P. L., Aldridge, R. J., 2000. Conodont Affinity and Chordate Phylogeny. Biological Reviews, 75(2): 191-251. https://doi.org/10.1111/j.1469-185x.1999.tb00045.x

Du, Y. X., Chiari, M., Karádi, V., et al., 2020a. The Asynchronous Disappearance of Conodonts: New Constraints from Triassic-Jurassic Boundary Sections in the Tethys and Panthalassa. Earth-Science Reviews, 203: 103176. https://doi.org/10.1016/j.earscirev.2020.103176

Du, Y. X., Bertinelli, A., Jin, X., et al., 2020b. Integrated Conodont and Radiolarian Biostratigraphy of the Upper Norian in Baoshan Block, Southwestern China. Lethaia, 53(4): 533-545. https://doi.org/10.1111/let.12374

Gale, L., Kolar-Jurkovšek, T., Šmuc, A., et al., 2012. Integrated Rhaetian Foraminiferal and Conodont Biostratigraphy from the Slovenian Basin, Eastern Southern Alps. Swiss Journal of Geosciences, 105(3): 435-462. https://doi.org/10.1007/s00015-012-0117-1

Gallet, Y., Krystyn, L., Marcoux, J., et al., 2007. New Constraints on the End-Triassic (Upper Norian-Rhaetian) Magnetostratigraphy. Earth and Planetary Science Letters, 255(3/4): 458-470. https://doi.org/10.1016/j.eps1.2007.01.004

Giordano, N., Ciarapica, G., Bertinelli, A., et al., 2011. The Norian-Rhaetian Interval in Two Sections of the Lagonegro Area: The Transition from Carbonate to Siliceous Deposition. Italian Journal of Geosciences, 130: 380-393. https://doi.org/10.3301/ijg.2011.11

Giordano, N., Rigo, M., Ciarapica, G., et al., 2010. New Biostratigraphical Constraints for the Norian/Rhaetian Boundary: Data from Lagonegro Basin, Southern Apennines, Italy. Lethaia, 43(4): 573-586. https://doi.org/10.1111/j.1502-3931.2010.00219.x

Guaiumi, C., Nicora, A., Preto, N., et al., 2007. New Biostratigraphic Data around the Carnian/Norian Boundary from the Pizzo Mondello Section, Sicani Mountains, Sicily. New Mexico Museum of Natural History and Science Bulletin, 41: 40-42

Guex, J., 2006. Reinitialization of Evolutionary Clocks during Sublethal Environmental Stress in some Invertebrates. Earth and Planetary Science Letters, 242(3/4): 240-253. https://doi.org/10.1016/j.eps1.2005.12.007

Guex, J., O’Dogherty, L., Carter, E. S., et al., 2012. Geometrical Transformations of Selected Mesozoic Radiolarians. Geobios, 45(6): 541-554. https://doi.org/10.1016/j.geobios.2012.04.001

Gullo, M., 1996. Conodont Biostratigraphy of Uppermost Triassic Deep-Water Calcilutites from Pizzo Mondello (Sicani Mountains): Evidence for Rhaetian Pelagites in Sicily. Palaeogeography, Palaeoclimatology, Palaeoecology, 126(3/4): 309-323. https://doi.org/10.1016/s0031-0182(96)00043-0

Hatch, J. R., Leventhal, J. S., 1992. Relationship between Inferred Redox Potential of the Depositional Environment and Geochemistry of the Upper Pennsylvanian (Missourian) Stark Shale Member of the Dennis Limestone, Wabaunsee County, Kansas, U.S.A. Chemical Geology, 99(1/2/3): 65-82. https://doi.org/10.1016/0009-2541(92)90031-y

Johnston, D. T., Poulton, S. W., Goldberg, T., et al., 2012. Late Ediacaran Redox Stability and Metazoan Evolution. Earth and Planetary Science Letters, 335/336: 25-35. https://doi.org/10.1016/j.epsl.2012.05.010

Jones, B., Manning, D. A. C., 1994. Comparison of Geochemical Indices Used for the Interpretation of Palaeoredox Conditions in Ancient Mudstones. Chemical Geology, 111(1/2/3/4): 111-129. https://doi.org/10.1016/0009-2541(94)90085-x

Karádi, V., Cau, A., Mazza, M., et al., 2020. The Last Phase of Conodont Evolution during the Late Triassic: Integrating Biostratigraphic and Phylogenetic Approaches. Palaeogeography, Palaeoclimatology, Palaeoecology, 549:
109144. https://doi.org/10.1016/j.palaeo.2019.03.045

Kozur, H., 1989. The Taxonomy of the Gondolellid Conodonts in the Permian and Triassic. Courier Forschungsinstitut Senckenberg, 117: 409-469

Kozur, H., Mock, R., 1972. Neue Conodonten aus der Trias der Slowakei und ihre Stratigraphische Bedeutung. Geologisch-Paläontologische Mitteilungen Innsbruck, 2(4): 1-20

Kozur, H., Mock, R., 1991. New Middle Carnian and Rhaetian Conodonts from Hungary and the Alps, Stratigraphic Importance and Tectonic Implications for the Buda Mountains and Adjacent Areas. Jahrbuch der Geologischen Bundesanstalt, 134: 271-297

Kozur, H., Mostler, H., 1971. Probleme der Conodontenforschung in der Trias. Geologische-Palaontologische Mitteilungen Innsbruck, 1(4): 1-19

Krystyn, L., Bouquerel, H., Kuerschner, W., et al., 2007a. Proposal for a Candidate GSSP for the Base of the Rhaetian Stage. In: Lucas, S. G., Spielmann, J. A., eds., The Global Triassic. New Mexico Museum of Natural History and Science Bulletin, 41: 189-199

Krystyn, L., Richoz, S., Gallet, Y., et al., 2007b. Updated Bio- and Magnetostratigraphy from Steinbergkogel (Austria), Candidate GSSP for the Base of the Rhaetian Stage. Albertiana, 36: 164-173

Kunihiro, S., Saito, H., Sakagami, S., 1984. Discovery of Triassic Conodonts from "Kurohae Chert" in the Choshi Peninsula. Journal of Geography (Chigaku Zasshi), 93(5): 341-343. https://doi.org/10.5026/jgeography.93.5_341

Lyons, T. W., Werne, J. P., Hollander, D. J., et al., 2003. Contrasting Sulfur Geochemistry and $\mathrm{Fe} / \mathrm{Al}$ and $\mathrm{Mo} / \mathrm{Al}$ Ratios across the Last Oxic-to-Anoxic Transition in the Cariaco Basin, Venezuela. Chemical Geology, 195(1/2/3/4): 131-157. https://doi.org/10.1016/s0009-2541(02)00392-3

Mazza, M., Furin, S., Spötl, C., et al., 2010. Generic Turnovers of Carnian/Norian Conodonts: Climatic Control or Competition?. Palaeogeography, Palaeoclimatology, Palaeoecology, 290(1/2/3/4): 120-137. https://doi.org/10.1016/j.palaeo.2009.07.006

Mazza, M., Martínez-Pérez, C., 2015. Unravelling Conodont (Conodonta) Ontogenetic Processes in the Late Triassic through Growth Series Reconstructions and X-Ray Microtomography. Bollettino della Società Paleontologica Italiana, 54(3): 161-186. https://doi.org/10.4435/bspi.2015.10

Mazza, M., Nicora, A., Rigo, M., 2018. Metapolygnathus parvus Kozur, 1972 (Conodonta): A Potential Primary Marker for the Norian GSSP (Upper Triassic). Bollettino della Società Paleontologica Italiana, 57(2): 81-101. https://doi.org/10.4435/bspi.2018.06

Mazza, M., Rigo, M., Gullo, M., 2012a. Taxonomy and Stratigraphic Record of the Upper Triassic Conodonts of the Pizzo Mondello Section (Western Sicily, Italy), GSSP Candidate for the Base of the Norian. Rivista Italiana di Paleontologia e Stratigrafia, 118: 85-130

Mazza, M., Cau, A., Rigo, M., 2012b. Application of Numerical Cladistic Analyses to the Carnian-Norian Conodonts: A New Approach for Phylogenetic Interpretations. Journal of Systematic Palaeontology, 10(3): 401-422. https://doi.org/10.1080/14772019.2011.573584

Mazza, M., Rigo, M., Nicora, A., et al., 2011. A New Metapolygnathus Platform Conodont Species and Its Implications for Upper Carnian Global Correlations. Acta Palaeontologica Polonica, 56(1): 121-131. https://doi.org/10.4202/app.2009.1104

Mietto, P., Manfrin, S., Preto, N., et al., 2012. The Global Boundary Stratotype Section and Point (GSSP) of the Carnian Stage (Late Triassic) at Prati di Stuores/Stuores Wiesen Section (Southern Alps, NE Italy). Episodes, 35(3): 414-430. https://doi.org/10.18814/epiiugs/2012/v35i3/003

Moix, P., Kozur, H. W., Stampfli, G. M., et al., 2007. New Paleontological, Biostratigraphic and Paleogeographic Results from the Triassic of the Mersin Mélange, SE Turkey. In: Lucas, S. G., Spielmann, J. A., eds., The Global Triassic. New Mexico Museum of Natural History and Sci- 
ence Bullettin, 41: 282-311

Muttoni, G., Kent, D. V., Di Stefano, P., et al., 2001. Magnetostratigraphy and Biostratigraphy of the Carnian/Norian Boundary Interval from the Pizzo Mondello Section (Sicani Mountains, Sicily). Palaeogeography, Palaeoclimatology, Palaeoecology, 166: 383-399. https://doi.org/10.1016/s0031-0182(00)00224-8

Muttoni, G., Kent, D. V., Olsen, P. E., et al., 2004. Tethyan Magnetostratigraphy from Pizzo Mondello (Sicily) and Correlation to the Late Triassic Newark Astrochronological Polarity Time Scale. Geological Society of America Bulletin, 116(9/10): 1043-1058. https://doi.org/10.1130/b25326.1

Nicora, A., Balini, M., Bellanca, A., et al., 2007. The Carnian/Norian Boundary Interval at Pizzo Mondello (Sicani Mountains, Sicily) and Its Bearing for the Definition of the GSSP of the Norian Stage. Albertiana, 36: 102-129

Onoue, T., Yamashita, K., Fukuda, C., et al., 2018. Sr Isotope Variations in the Upper Triassic Succession at Pizzo Mondello, Sicily: Constraints on the Timing of the Cimmerian Orogeny. Palaeogeography, Palaeoclimatology, Palaeoecology, 499: 131-137. https://doi.org/10.1016/j.palaeo.2018.03.025

Onoue, T., Zonneveld, J. P., Orchard, M. J., et al., 2016. Paleoenvironmental Changes across the Carnian/Norian Boundary in the Black Bear Ridge Section, British Columbia, Canada. Palaeogeography, Palaeoclimatology, Palaeoecology, 441: 721-733. https://doi.org/10.1016/j.palaeo.2015.10.008

Orchard, M. J., 1983. Epigondolella Populations and Their Phylogeny and Zonation in the Upper Triassic. Fossils and Strata, 15: 177-192

Orchard, M. J., 2018. The Lower-Middle Norian (Upper Triassic) Boundary: New Conodont Taxa and a Refined Biozonation. In: Over, D. J., Henderson, C. M., eds., Conodont Studies Dedicated to the Careers and Contributions of Anita Harris, Glen Merrill, Carl Rexroad, Walter Sweet, and Bruce Wardlaw. Bulletins of American Paleontology, 395/396: 165-193. https://doi.org/10.32857/bap.2018.395.12

Orchard, M. J., Carter, E. S., Lucas, S. G., et al., 2007a. Rhaetian (Upper Triassic) Conodonts and Radiolarians. Albertiana, 35: 59-65

Orchard, M. J., Whalen, P. A., Carter, E. S., et al., 2007b. Latest Triassic Conodonts and Radiolarian-Bearing Successions in Baja California Sur. In: Lucas, S. G., Spielmann, J. A., eds., The Global Triassic. New Mexico Museum of Natural History and Science Bulletin, 41: 355-365

Pálfy, J., Demény, A., Haas, J., et al., 2007. Triassic-Jurassic Boundary Events Inferred from Integrated Stratigraphy of the Csővár Section, Hungary. Palaeogeography, Palaeoclimatology, Palaeoecology, 244(1/2/3/4): 11-33. https://doi.org/10.1016/j.palaeo.2006.06.021

Preto, N., Agnini, C., Rigo, M., et al., 2013. The Calcareous Nannofossil Prinsiosphaera Achieved Rock-Forming Abundances in the Latest Triassic of Western Tethys: Consequences for the $\delta^{13} \mathrm{C}$ of Bulk Carbonate. Biogeosciences Discussions, 10(5): 7989-8025. https://doi.org/10.5194/bgd-10-7989-2013

Preto, N., Rigo, M., Agnini, C., et al., 2012. Triassic and Jurassic Calcareous Nannofossils of the Pizzo Mondello Section: A SEM Study. Rivista Italiana di Paleontologia e Stratigrafia, 118(1): 133-141. https://doi.org/10.13130/2039-4942/5994

Reggiani, L., Bertinelli, A., Ciarapica, G., et al., 2005. Triassic-Jurassic Stratigraphy of the Madonna del Sirino Succession (Lagonegro Basin, Southern Apennines, Italy). Bollettino Della Società Geologica Italiana, 124(Suppl.): 281-291

Rigo, M., Bertinelli, A., Concheri, G., et al., 2016. The Pignola-Abriola Section (Southern Apennines, Italy): A New GSSP Candidate for the Base of the Rhaetian Stage. Lethaia, 49(3): 287-306. https://doi.org/10.1111/let.12145

Rigo, M., De Zanche, V., Mietto, P., et al., 2005. Correlation of Upper Triassic Sections throughout the Lagonegro Basin. Bollettino della Societa
Geologica Italiana, 124: 293-300

Rigo, M., Joachimski, M. M., 2010. Palaeoecology of Late Triassic Conodonts: Constraints from Oxygen Isotopes in Biogenic Apatite. Acta Palaeontologica Polonica, 55(3): 471-478. https://doi.org/10.4202/app.2009.0100

Rigo, M., Mazza, M., Karádi, V., et al., 2018. New Upper Triassic Conodont Biozonation of the Tethyan Realm. In: Tanner, L. H., ed., The Late Triassic World. Topics in Geobiology 46. Springer, Cham. 189-235. https://doi.org/10.1007/978-3-319-68009-5_6

Rigo, M., Onoue, T., Tanner, L. H., et al., 2020. The Late Triassic Extinction at the Norian/Rhaetian Boundary: Biotic Evidence and Geochemical Signature. Earth-Science Reviews, 204: 103180. https://doi.org/10.1016/j.earscirev.2020.103180

Rigo, M., Preto, N., Roghi, G., et al., 2007. A Rise in the Carbonate Compensation Depth of Western Tethys in the Carnian (Late Triassic): Deep-Water Evidence for the Carnian Pluvial Event. Palaeogeography, Palaeoclimatology, Palaeoecology, 246: 188-205. https://doi.org/10.1016/j.palaeo.2006.09.013

Rigo, M., Trotter, J. A., Preto, N., et al., 2012. Oxygen Isotopic Evidence for Late Triassic Monsoonal Upwelling in the Northwestern Tethys. Geology, 40(6): 515-518. https://doi.org/10.1130/g32792.1

Rimmer, S. M., 2004. Geochemical Paleoredox Indicators in DevonianMississippian Black Shales, Central Appalachian Basin (USA). Chemical Geology, 206(3/4): 373-391. https://doi.org/10.1016/j.chemgeo.2003.12.029

Rudnick, R. L., Gao, S., 2014. Composition of the Continental Crust. In: Holland, H. D., Turekian, K. K., eds., Treatise on Geochemistry. Elsevier Sci. 4, Amsterdam. 1-51. https://doi.org/10.1016/B978-0-08-095975-7.00301-6

Sansom, I., Smith, M., Armstrong, H., et al., 1992. Presence of the Earliest Vertebrate Hard Tissue in Conodonts. Science, 256(5061): 1308-1311. https://doi.org/10.1126/science.1598573

Schovsbo, N. H., 2001. Why Barren Intervals? A Taphonomic Case Study of the Scandinavian Alum Shale and Its Faunas. Lethaia, 34(4): 271-285. https://doi.org/10.1111/j.1502-3931.2001.tb00056.x

Sholkovitz, E. R., Landing, W. M., Lewis, B. L., 1994. Ocean Particle Chemistry: The Fractionation of Rare Earth Elements between Suspended Particles and Seawater. Geochimica et Cosmochimica Acta, 58(6): 1567-1579. https://doi.org/10.1016/0016-7037(94)90559-2

Soda, K., Onoue, T., 2019. Multivariate Analysis of Geochemical Compositions of Bedded Chert during the Middle Triassic (Anisian) Oceanic Anoxic Events in the Panthalassic Ocean. Geochemical Journal, 53(2): 91-102. https://doi.org/10.2343/geochemj.2.0540

Trotter, J. A., Williams, I. S., Barnes, C. R., et al., 2008. Did Cooling Oceans Trigger Ordovician Biodiversification? Evidence from Conodont Thermometry. Science, 321(5888): 550-554. https://doi.org/10.1126/science.1155814

Trotter, J. A., Williams, I. S., Nicora, A., et al., 2015. Long-Term Cycles of Triassic Climate Change: A New $\delta^{18} \mathrm{O}$ Record from Conodont Apatite. Earth and Planetary Science Letters, 415: 165-174. https://doi.org/10.1016/j.eps1.2015.01.038

Wignall, P. B., Zonneveld, J. P., Newton, R. J., et al., 2007. The End Triassic Mass Extinction Record of Williston Lake, British Columbia. Palaeogeography, Palaeoclimatology, Palaeoecology, 253(3/4): 385-406. https://doi.org/10.1016/j.palaeo.2007.06.020

Zhang, L., Orchard, M. J., Algeo, T. J., et al., 2019. An Intercalibrated Triassic Conodont Succession and Carbonate Carbon Isotope Profile, Kamura, Japan. Palaeogeography, Palaeoclimatology, Palaeoecology, 519: 65-83. https://doi.org/10.1016/j.palaeo.2017.09.001 